\title{
Novosphingobium taihuense sp. nov., a novel aromatic-compound-degrading bacterium isolated from Taihu Lake, China
}

\author{
Correspondence \\ Shuang-Jiang Liu \\ shuangjiang@hotmail.com
}

\author{
Zhi-Pei Liu, Bao-Jun Wang, Ying-Hao Liu and Shuang-Jiang Liu \\ State Key Laboratory of Microbial Resources and Institute of Microbiology, Chinese Academy \\ of Sciences, ZhongGuanCun, Haidian, Beijing 100080, PR China
}

\begin{abstract}
A novel aromatic-compound-degrading bacterium, strain $\mathrm{T}_{3}-\mathrm{B}^{\top}{ }^{\top}$, was isolated from sediment of Taihu Lake, Jiangsu Province, south-east China. This bacterial isolate assimilated several aromatic compounds such as phenol, aniline, nitrobenzene, 4-chloronitrobenzene and phenanthrene. The taxonomy of strain $\mathrm{T} 3-\mathrm{Bg}^{\top}$ was studied by polyphasic methods. The organism showed a range of phenotypic and chemotaxonomic properties consistent with those of the genus Novosphingobium. The $16 \mathrm{~S}$ rRNA gene sequence similarity of strain T3-B9 ${ }^{\top}$ to members of the genus Novosphingobium ranged from 91.6 to $97 \cdot 5 \%$, and this isolate clustered phylogenetically with members of genus Novosphingobium. The DNA-DNA relatedness values of strain T3-B9 ${ }^{\top}$ to the most phylogenetically related species, Novosphingobium subterraneum DSM $12447^{\top}$, Novosphingobium aromaticivorans ATCC $700278^{\top}$ and Novosphingobium stygium ATCC $700280^{\top}$, were 31,33 and $14 \%$, respectively. The combined genotypic and phenotypic data show that strain $\mathrm{T} 3-\mathrm{B} 9^{\top}$ represents a novel species of the genus Novosphingobium, for which the name Novosphingobium taihuense sp. nov. is proposed. The type strain is $\mathrm{T3}-\mathrm{Bg}^{\top}\left(=\mathrm{AS} 1.3432^{\top}=\mathrm{JCM} 12465^{\mathrm{T}}\right)$.
\end{abstract}

The genus Novosphingobium was created by Takeuchi et al. (2001) to accommodate species of the genus Sphingomonas (Yabuuchi et al., 1990) that clustered phylogenetically with Novosphingobium capsulatum [cluster III of Takeuchi et al. (2001)], have 2-OH 14:0 as the major 2-hydroxy fatty acid and spermidine as the major polyamine and are able to reduce nitrate (Takeuchi et al., 2001). Although Yabuuchi et al. (2002) argued that the creation of the genus Novosphingobium required more phenotypic support, many sphingomonad taxonomists (Kämpfer et al., 2002; Fujii et al., 2003; Sohn et al., 2004; Tiirola et al., 2005) adhere to the proposal of Takeuchi et al. (2001) because of phylogenetic and also chemotaxonomic studies that clearly separate Novosphingobium from the genus Sphingomonas sensu stricto. Currently, the genus Novosphingobium includes the following species with validly published names: Novosphingobium aromaticivorans (Balkwill et al., 1997), Novosphingobium capsulatum (Leifson, 1962; Yabuuchi et al., 1990), Novosphingobium hassiacum (Kämpfer et al., 2002), Novosphingobium pentaromativorans (Sohn et al., 2004),

Published online ahead of print on 7 January 2005 as DOI 10.1099/ ijs.0.63468-0.

The GenBank/EMBL/DDBJ accession number for the 16S rRNA gene sequence of strain $\mathrm{T3}^{-B 9^{\top}}$ is $A Y 500142$.

The polar lipid profile of strain T3-B9 ${ }^{\top}$ and a phylogenetic tree for Novosphingobium species constructed using the maximum-parsimony method are available as supplementary material in IJSEM Online.
Novosphingobium rosa (Takeuchi et al., 1995), Novosphingobium stygium (Balkwill et al., 1997), Novosphingobium subarcticum (Nohynek et al., 1996), Novosphingobium subterraneum (Balkwill et al., 1997), Novosphingobium tardaugens (Fujii et al., 2003) and Novosphingobium lentum (Tiirola et al., 2005). The organisms of this genus are inhabitants of soil, sediments and other subsurfaces and are able to degrade various xenobiotic aromatic compounds (Stevens et al., 1993; Fredrickson et al., 1995; Karlson et al., 1995; Kim et al., 1996; Wildes et al., 1996; Balkwill et al., 1997). Thus, they are potentially important in the biogeochemical cycles of carbon, nitrogen or chlorine, elements of xenobiotic compounds in their surrounding environments. They have also potential biotechnological applications, for example, the bioremediation of aromatic-contaminated environments.

During a systematic investigation of the microbial ecology and elemental biogeochemistry of Taihu Lake, located in south-east China, a yellow-pigmented bacterial strain, designated strain $\mathrm{T} 3-\mathrm{B}^{\mathrm{T}}$, was isolated from a lake sediment sample (GPS location of sampling site is $120^{\circ} 02^{\prime}$ $16 \cdot 8^{\prime \prime}$ E $\left.31^{\circ} 27^{\prime} 10 \cdot 7^{\prime \prime} \mathrm{N}\right)$. Sediment samples were obtained at $10 \mathrm{~cm}$ beneath the sediment surface. Strain $\mathrm{T} 3-\mathrm{B} 9^{\mathrm{T}}$ was isolated by plating $0.1 \mathrm{ml}$ of 10 -fold dilutions of the sample onto diluted LB agar $(0 \cdot 1 \%$ peptone, $0.05 \%$ yeast extract, $0 \cdot 1 \% \mathrm{NaCl}, 1 \cdot 5 \%$ agar). Routine cultivation was conducted aerobically with LB agar or LB broth at $30^{\circ} \mathrm{C}$. 
Gram staining was conducted according to the method described by Gerhardt et al. (1994). Oxidase activity, indole production and hydrolysis of starch etc. were tested according to the methods described by Dong \& Cai (2001). Spore formation was determined by malachite green staining of cells grown on LB agar. Flagellation was examined by using a transmission electron microscope (H-600; Hitachi) at $100 \mathrm{kV}$ after negative staining with $1 \%$ (w/v) phosphotungstic acid. Morphological observation was carried out using a scanning electron microscope (FEI Quanta 2000). For assaying assimilation of aromatic compounds, each compound was added at a concentration of $30 \mathrm{mg} \mathrm{l}^{-1}$ to mineral medium broth (Liu et al., 2002). Growth was examined after incubation at $30^{\circ} \mathrm{C}$ for 1 week. Denitrification was determined by the method of Stanier et al. (1966). Catalase activity was judged by formation of bubbles after a $3 \% \mathrm{H}_{2} \mathrm{O}_{2}$ solution was dropped onto a fresh colony. Aerobic and anaerobic production of acids (OF reaction) from carbohydrates was determined in OF basal medium (Hugh \& Leifson, 1953). Carbohydrate solutions, sterilized by filtration, were added at a final concentration of $1 \%(\mathrm{w} / \mathrm{v})$ and acid production from carbohydrates was recorded after 7 and 14 days of incubation. Cellular fatty acids were extracted from cells grown in LB broth at $30^{\circ} \mathrm{C}$ and subsequently purified and analysed as described previously (Hu et al., 2004 and papers cited therein). For the analysis of polar lipids and quinones, strain $\mathrm{T} 3-\mathrm{B}^{\mathrm{T}}$ was grown at $22{ }^{\circ} \mathrm{C}$ in $\mathrm{R} 2 \mathrm{~A}$ broth; cells were harvested at the late-exponential phase, centrifuged and lyophilized. Polar lipids were examined by two-dimensional TLC and characterized with spreading reagents specific for $\alpha$-glycols (periodate-Schiff), sugars ( $\alpha$-naphthol- $\mathrm{H}_{2} \mathrm{SO}_{4}$, anisaldehyde- $\mathrm{H}_{2} \mathrm{SO}_{4}$ ) and phosphate (Zindzadze) (Ventosa et al., 1993). Quinones were determined according to Collins (1985) and Wu et al. (1989). DNA base compositions were determined by thermal denaturation (Marmur \& Doty, 1962) and DNA from Escherichia coli DH-5 $\alpha$ was used as standard for the calibration of the $T_{\mathrm{m}}$ value. The $16 \mathrm{~S}$ rRNA gene was amplified and sequenced as described previously (Zhang et al., 2003). 16S rRNA gene sequence alignments were performed using the CLUSTAL X program (Thompson et al., 1997). Phylogenetic trees were constructed with the neighbour-joining (Saitou \& Nei, 1987) and maximumparsimony methods. DNA-DNA hybridization was performed by the thermal denaturation and renaturation method of De Ley et al. (1970) and modified by Huß et al. (1983).

Cells of strain $\mathrm{T} 3-\mathrm{B} 9^{\mathrm{T}}$ were Gram-negative, aerobic, nonspore-forming, non-motile rods, about $0.45 \times 1 \cdot 8 \sim$ $4 \cdot 0 \mu \mathrm{m}$. The strain produced small (about $2 \mathrm{~mm}$ ), yellow colonies on 10-fold-diluted LB agar, LB agar or R2A agar after 3 days cultivation. The optimal temperature for growth of strain $\mathrm{T} 3-\mathrm{B} 9^{\mathrm{T}}$ was $25^{\circ} \mathrm{C}$; growth was observed at $10-37^{\circ} \mathrm{C}$, but not at 4 or $40^{\circ} \mathrm{C}$. The optimal $\mathrm{pH}$ for growth was $6 \cdot 0$; growth occurred at $\mathrm{pH} 4 \cdot 5-8 \cdot 5$, but not at $\mathrm{pH} 4.0$ or $9 \cdot 0$. It assimilated the following aromatic compounds for growth: phenol, 3-aminophenol, aniline, nitrobenzene, 4-chloronitrobenzene, 3-hydroxybenzoate and phenanthrene, but not 3- or 4-chloroaniline, chlorobenzene, 3,5-dihydroxytoluene, anthracene or pyrene.

Strain $\mathrm{T} 3-\mathrm{B} 9^{\mathrm{T}}$ reduced nitrate, but did not produce $\mathrm{N}_{2}$, consistent with the properties of the genus Novosphingobium (Takeuchi et al., 2001). $\mathrm{H}_{2} \mathrm{~S}$ was not produced. Catalase activity was positive. Additional features and some properties that differentiate strain $\mathrm{T} 3-\mathrm{B} 9^{\mathrm{T}}$ from other members of the genus Novosphingobium are given in Table 1. Strain $\mathrm{T} 3-\mathrm{B9}^{\mathrm{T}}$ contained $18: 1$ as the dominant fatty acid and 2-OH 14:0 as the major hydroxylated fatty acid. The cellular fatty acid profile of strain $\mathrm{T} 3-\mathrm{B} 9^{\mathrm{T}}$ is outlined in the species description. Strain $\mathrm{T} 3-\mathrm{B} 9^{\mathrm{T}}$ contained

Table 1. Differentiation of strain $\mathrm{T}^{-}-\mathrm{Bg}^{\mathrm{T}}$ from other Novosphingobium species

Strains: 1, T3-B9 ${ }^{\mathrm{T}}$; 2, N. hassiacum DSM $14552^{\mathrm{T}}$ (data from Kämpfer et al., 2002) 3, N. tardaugens JCM $11434^{\mathrm{T}}$ (Fujii et al., 2003); 4, N. subarcticum JCM $10398^{\mathrm{T}}$; 5 , N. subterraneum DSM $12447^{\mathrm{T}}$; 6, N. stygium ATCC $700280^{\mathrm{T}}$ (data for columns 4-6 from Balkwill et al., 1997); 7, N. capsulatum ATCC $14666^{\mathrm{T}}$ (Kämpfer et al., 1997); 8, N. rosa ATCC $51837^{\mathrm{T}}$ (Kämpfer et al., 1997); 9, N. aromaticivorans ATCC $700278^{\mathrm{T}}$ (Balkwill et al., 1997); 10, N. pentaromativorans KCTC $10454^{\mathrm{T}}$ (Sohn et al., 2004); 11, N. lentum DSM $13663^{\mathrm{T}}$ (Tiirola et al., 2005). +, Positive; -, negative; $(+)$, weakly positive; ND, not detected or not described. All strains were positive for catalase and nitrate reduction. All strains were negative for arginine dihydrolase and urease activity, production of indole, glucose fermentation, denitrification and assimilation of adonitol, $\beta$-alanine, citrate, D-sorbitol, L-phenylalanine, phenylacetate and D-ribose.

\begin{tabular}{|c|c|c|c|c|c|c|c|c|c|c|c|}
\hline Characteristic & 1 & 2 & 3 & 4 & 5 & 6 & 7 & 8 & 9 & 10 & 11 \\
\hline \multicolumn{12}{|l|}{ Assimilation of: } \\
\hline $\begin{array}{l}N \text {-Acetyl-D- } \\
\text { glucosamine }\end{array}$ & - & - & - & + & - & - & + & $(+)$ & + & - & - \\
\hline L-Arabinose & + & - & - & + & - & - & $(+)$ & + & - & - & - \\
\hline D-Cellobiose & + & + & - & - & + & - & + & + & + & - & - \\
\hline D-Fructose & + & - & - & - & - & - & - & + & - & + & - \\
\hline D-Galactose & - & - & - & + & - & - & + & - & - & - & - \\
\hline D-Glucose & + & $(+)$ & - & + & + & - & + & + & + & - & - \\
\hline D-Mannose & + & - & - & - & + & - & $(+)$ & + & + & - & - \\
\hline D-Maltose & + & - & - & + & + & - & + & + & + & - & - \\
\hline D-Melibiose & - & - & - & - & + & - & - & + & - & - & - \\
\hline L-Rhamnose & + & - & - & + & + & - & + & + & + & + & - \\
\hline Sucrose & + & - & - & - & + & - & + & + & + & + & - \\
\hline D-Trehalose & - & - & - & - & - & - & + & - & - & + & - \\
\hline D-Xylose & + & - & - & + & + & - & + & + & + & - & - \\
\hline D-Mannitol & - & - & - & + & - & + & - & - & - & $\mathrm{ND}$ & - \\
\hline L-Alanine & + & - & - & + & - & - & - & - & - & - & - \\
\hline L-Proline & + & + & - & + & + & - & - & - & + & + & - \\
\hline \multicolumn{12}{|l|}{ Hydrolysis of: } \\
\hline Gelatin & - & + & - & + & - & - & - & - & - & - & - \\
\hline Aesculin & + & - & ND & + & + & + & + & $(+)$ & + & + & - \\
\hline Oxidase activity & - & + & - & - & - & - & - & - & - & - & - \\
\hline
\end{tabular}


sphingoglycolipid, phosphatidylethanolamine and diphosphatidylglycerol as major identified polar lipids (see Supplementary Fig. A in IJSEM Online). The unidentified phospholipid PLxl was most likely identical to the corresponding unidentified phospholipids of N. lentum (PLx1; Tiirola et al., 2005) and of N. hassiacum (PL; Kämpfer et al., 2002). The unidentified polar lipids Lx1 and PLx2 of strain $\mathrm{T} 3-\mathrm{B} 9^{\mathrm{T}}$ were most likely identical to the corresponding polar lipids Lx1 and PLx2 of N. lentum (Tiirola et al., 2005). Strain $\mathrm{T} 3-\mathrm{B} 9^{\mathrm{T}}$ showed more unidentified polar lipids, Lx2 and Lx3, when compared to N. lentum (Tiirola et al., 2005), and phosphatidylmonomethylethanolamine (PME) was not detected. The combined presence of unknown polar lipids and the absence of PME clearly distinguishes $\mathrm{T} 3-\mathrm{B} 9^{\mathrm{T}}$ from other species of Novosphingobium, including $N$. aromaticivorans, $N$. capsulatum, $N$. stygium, $N$. subterraneum, $N$. subarcticum, N. rosa (Busse et al., 1999), N. hassiacum (Kämpfer et al., 2002) and N. lentum (Tiirola et al., 2005). The predominant isoprenoid quinone of strain $\mathrm{T} 3-\mathrm{B} 9^{\mathrm{T}}$ was Q-10. The G $+\mathrm{C}$ content of strain $\mathrm{T} 3-\mathrm{B} 9^{\mathrm{T}}$ was $63 \cdot 3 \mathrm{~mol} \%$ $\left(T_{\mathrm{m}}\right)$, which is in accordance with the range described for the genus Novosphingobium (62-67 mol\%; Takeuchi et al., 2001). All these data indicate that strain $\mathrm{T} 3-\mathrm{B} 9^{\mathrm{T}}$ is a member of the genus Novosphingobium.

The sequence of the $16 \mathrm{~S}$ rRNA gene of strain $\mathrm{T} 3-\mathrm{B} 9^{\mathrm{T}}$ was aligned with others of members of the genus Novosphingobium and results showed the signature nucleotides of Novosphingobium: 52C, 134G, 359G, 593U, 987G, 990U, $1215 \mathrm{~A}$ and $1218 \mathrm{C}$ (Takeuchi et al., 2001). Strain T3-B9 ${ }^{\mathrm{T}}$ showed levels of $16 \mathrm{~S}$ rDNA gene sequence (1362 base pairs) similarity ranging from $91 \cdot 6$ to $97 \cdot 5 \%$ to members of the genus Novosphingobium, with the highest to N. subterraneum DSM $12447^{\mathrm{T}}(97 \cdot 5 \%)$ and $N$. aromaticivorans ATCC $700278^{\mathrm{T}}(97 \cdot 2 \%)$. A neighbour-joining tree (Fig. 1) showed that strain $\mathrm{T} 3-\mathrm{B} 9^{\mathrm{T}}$ formed coherent clades with other members of the genus Novosphingobium and it clustered closely with $N$. stygium ATCC $700280^{\mathrm{T}}$ (75\% bootstrap support). A tree derived by the maximum-parsimony method is available as Supplementary Fig. B in IJSEM Online. The DNA-DNA relatedness of strain $\mathrm{T} 3-\mathrm{B} 9^{\mathrm{T}}$ to $N$. subterraneum DSM $12447^{\mathrm{T}}$, N. aromaticivorans ATCC $700278^{\mathrm{T}}$ and N. stygium ATCC $700280^{\mathrm{T}}$ was 31,33 and $14 \%$, respectively.

Combining the above phenotypic, chemotaxonomic and genotypic results, we conclude that strain $\mathrm{T} 3-\mathrm{B} 9^{\mathrm{T}}$ represents a novel species of the genus Novosphingobium, for which the name Novosphingobium taihuense is proposed.

\section{Description of Novosphingobium taihuense sp. nov.}

Novosphingobium taihuense (tai.hu.en'se. N.L. neut. adj. taihuense pertaining to Taihu Lake, the source of the sediment from which the type strain was isolated).

Cells are Gram-negative, aerobic, non-spore-forming, nonmotile rods. Produces small (about $2 \mathrm{~mm}$ ), yellow colonies

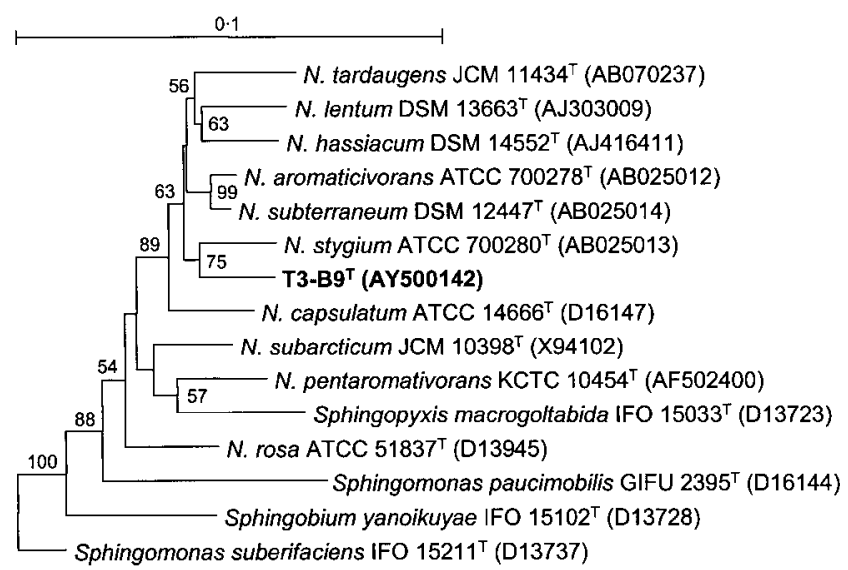

Fig. 1. Phylogenetic tree constructed with the neighbour-joining method based on 16S rRNA gene sequence alignments of strain T3-B9 ${ }^{\top}$ and related bacteria. Numbers at nodes indicate percentage levels of bootstrap support based on 1000 resampled datasets; only values greater than $50 \%$ are shown. Sphingomonas suberifaciens IFO $15211^{\top}$ was used as the outgroup. Bar, evolutionary distance $\left(K_{\text {nuc }}\right)$ of $0 \cdot 1$. A maximum-parsimony tree is available as supplementary material in IJSEM Online.

on 10-fold dilution of LB agar, LB agar or R2A agar, after incubation at $30^{\circ} \mathrm{C}$ for 3 days. The colonies are smooth, shiny, flat, non-transparent, elevated and rubbery. Growth occurs at $10-37^{\circ} \mathrm{C}, \mathrm{pH} 4 \cdot 5-8 \cdot 5$ and $0-2 \cdot 0 \% \mathrm{NaCl}$; optimal growth temperature, $\mathrm{pH}$ and salinity are $25^{\circ} \mathrm{C}, \mathrm{pH} 6.0$ and $0.5 \% \mathrm{NaCl}$. Positive for catalase activity and nitrate reduction. Activity of oxidase, urease and arginine dihydrolase, production of indole, growth on citrate, hydrolysis of starch and gelatin and glucose fermentation are all negative. Other characteristics are listed in Table 1. The dominant fatty acid is $18: 1(36.5 \%)$ and the major hydroxylated fatty acid is $2-\mathrm{OH} 14: 0(12 \cdot 8 \%)$. The fatty acid profile also contains $15: 0(2 \cdot 4 \%), 16: 0(9 \cdot 9 \%), 16: 1$ $(11 \cdot 9 \%), 17: 0(1 \cdot 9 \%), 17: 1(17 \cdot 3 \%), 18: 0(0 \cdot 7 \%), 13: 0$ 2-OH (0.9\%), 2-OH 15:0 (4.6\%) and 2-OH 16:0 (0.6\%). The predominant isoprenoid quinone is Q-10. Cells contain phosphatidylethanolamine, phosphatidylglycerol, diphosphatidylglycerol, sphingoglycolipid and an unknown polar lipid as major polar lipids; it also contains phosphatidylcholine, unknown phosphoglycolipids and other unknown polar lipids or phospholipids. DNA G $+\mathrm{C}$ content is $63 \cdot 3 \mathrm{~mol} \%\left(T_{\mathrm{m}}\right)$.

The type strain is $\mathrm{T} 3-\mathrm{B} 9^{\mathrm{T}}\left(=\mathrm{AS} 1.3432^{\mathrm{T}}=\mathrm{JCM} 12465^{\mathrm{T}}\right)$, isolated from sediment of Taihu Lake, Jiangsu Province, China.

\section{Acknowledgements}

This work was supported by grants from the Chinese Academy of Sciences (KZCX1-SW-12-II-02-02) and the National Nature Science Foundation of China (30230010). We thank Mr Y.-G. Zhou for his help with maintenance of the strain and its deposit in culture collections. 


\section{References}

Balkwill, D. L., Drake, G. R., Reeves, R. H. \& 7 other authors (1997). Taxonomic study of aromatic-degrading bacteria from deepterrestrial-subsurface sediments and description of Sphingomonas aromaticivorans sp. nov., Sphingomonas subterranea sp. nov., and Sphingomonas stygia sp. nov. Int J Syst Bacteriol 47, 191-201.

Busse, H.-J., Kämpfer, P. \& Denner, E. B. M. (1999). Chemotaxonomic characterisation of Sphingomonas. $J$ Ind Microbiol Biotechnol 23, 242-251.

Collins, M. D. (1985). Isoprenoid quinone analyses in classification and identification. In Chemical Methods in Bacterial Systematics, pp. 267-287. Edited by M. Goodfellow \& D. E. Minnikin. Orlando: Academic Press.

De Ley, J., Cattoir, H. \& Reynaerts, A. (1970). The quantitative measurement of DNA hybridization from renaturation rates. Eur J Biochem 12, 133-142.

Dong, X.-Z. \& Cai, M.-Y. (2001). Determinative Manual for Routine Bacteriology. Beijing: Scientific Press (English translation).

Fredrickson, J. K., Balkwill, D. L., Drake, G. R., Romine, M. F., Ringelberg, D. B. \& White, D. C. (1995). Aromatic-degrading Sphingomonas isolates from the deep subsurface. Appl Environ Microbiol 61, 1917-1922.

Fujii, K., Satomi, M., Morita, N., Motomura, T., Tanaka, T. \& Kikuchi, S. (2003). Novosphingobium tardaugens sp. nov., an oestradiol-degrading bacterium isolated from activated sludge of a sewage treatment plant in Tokyo. Int J Syst Evol Microbiol 53, 47-52.

Gerhardt, P., Murray, R. G. E., Wood, W. A. \& Krieg, N. R. (1994). Methods for General and Molecular Bacteriology. Washington, DC: American Society for Microbiology.

Hu, Y.-T., Zhou, P.-J., Zhou, Y.-G., Liu, Z.-H. \& Liu, S.-J. (2004). Saccharothrix xinjiangensis sp. nov., a pyrene-degrading actinomycete isolated from Tianchi lake, Xinjiang, China. Int J Syst Evol Microbiol 54, 2091-2094.

Hugh, R. \& Leifson, E. (1953). The taxonomic significance of fermentative versus oxidative metabolism of carbohydrates by various gram negative bacteria. J Bacteriol 66, 24-26.

Huß, V. A. R., Festl, H. \& Schleifer, K. H. (1983). Studies on the spectrometric determination of DNA hybridization from renaturation rates. Syst Appl Microbiol 4, 184-192.

Kämpfer, P., Denner, E. B. M., Meyer, S., Moore, E. R. B. \& Busse, H.-J. (1997). Classification of "Pseudomonas azotocolligans" Anderson 1955, 132, in the genus Sphingomonas as Sphingomonas trueperi sp. nov. Int J Syst Bacteriol 47, 577-583.

Kämpfer, P., Witzenberger, R., Denner, E. B. M., Busse, H.-J. \& Neef, A. (2002). Novosphingobium hassiacum sp. nov., a new species isolated from an aerated sewage pond. Syst Appl Microbiol 25, 37-45.

Karlson, U., Rojo, F., van Elsas, J. D. \& Moore, E. (1995). Genetic and serological evidence for the recognition of four pentachlorophenoldegrading bacterial strains as a species of the genus Sphingomonas. Syst Appl Microbiol 18, 539-548.

Kim, E., Aversano, P. J., Romine, M. F., Schneider, R. P. \& Zylstra, G. J. (1996). Homology between genes for aromatic hydrocarbon degradation in surface and deep-subsurface Sphingomonas strains. Appl Environ Microbiol 62, 1467-1470.

Leifson, E. (1962). The bacterial flora of distilled and stored water. III. New species of the genera Corynebacterium, Flavobacterium, Spirillum, and Pseudomonas. Int Bull Bacteriol Nomencl Taxon 12, 161-170.

Liu, Z., Yang, H., Huang, Z., Zhou, P. \& Liu, S.-J. (2002). Degradation of aniline by newly isolated, extremely aniline-tolerant Delftia sp. AN3. Appl Microbiol Biotechnol 58, 679-682.
Marmur, J. \& Doty, P. (1962). Determination of the base composition of deoxyribonucleic acid from its thermal denaturation temperature. J Mol Biol 5, 109-118.

Nohynek, L. J., Nurmiaho-Lassila, E. L., Suhonen, E. L., Busse, H.-J., Mohammadi, M., Hantula, J., Rainey, F. \& Salkinoja-Salonen, M. S. (1996). Description of chlorophenol-degrading Pseudomonas sp. strains $\mathrm{KF}^{\mathrm{T}}, \mathrm{KF} 3$, and NKF1 as a new species of the genus Sphingomonas, Sphingomonas subarctica sp. nov. Int J Syst Bacteriol 46, 1042-1055.

Saitou, N. \& Nei, M. (1987). The neighbor-joining method: a new method for reconstructing phylogenetic trees. Mol Biol Evol 4, 406-425.

Sohn, J. H., Kwon, K. K., Kang, J. H., Jung, H.-B. \& Kim, S.-J. (2004) Novosphingobium pentaromativorans sp. nov., a high-molecular-mass polycyclic aromatic hydrocarbon-degrading bacterium isolated from estuarine sediment. Int J Syst Evol Microbiol 54, 1483-1487.

Stanier, R. Y., Palleroni, N. J. \& Doudoroff, M. (1966). The aerobic pseudomonads: a taxonomic study. J Gen Microbiol 43, 159-271.

Stevens, T. O., McKinley, J. P. \& Fredrickson, J. K. (1993). Bacteria associated with deep, alkaline, anaerobic groundwaters in southeast Washington. Microb Ecol 25, 35-50.

Takeuchi, M., Sakane, T., Yanagi, M., Yamasato, K., Hamana, K. \& Yokota, A. (1995). Taxonomic study of bacteria isolated from plants: proposal of Sphingomonas rosa sp. nov., Sphingomonas pruni sp. nov., Sphingomonas asaccharolytica sp. nov., and Sphingomonas mali sp. nov. Int J Syst Bacteriol 45, 334-341.

Takeuchi, M., Hamana, K. \& Hiraishi, A. (2001). Proposal of the genus Sphingomonas sensu stricto and three new genera, Sphingobium, Novosphingobium and Sphingopyxis, on the basis of phylogenetic and chemotaxonomic analyses. Int J Syst Evol Microbiol 51, 1405-1417.

Thompson, J. D., Gibson, T. J., Plewniak, F., Jeanmougin, F. \& Higgins, D. G. (1997). The CLUSTAL_X Windows interface: flexible strategies for multiple sequence alignment aided by quality analysis tools. Nucleic Acids Res 25, 4876-4882.

Tiirola, M. A., Busse, H.-J., Kämpfer, P. \& Männistö, M. (2005). Novosphingobium lentum sp. nov., a psychrotolerant bacterium from a polychlorophenol bioremediation process. Int J Syst Evol Microbiol 55, 583-588

Ventosa, A., Marquez, M. C., Kocur, M. \& Tindall, B. J. (1993). Comparative study of "Micrococcus sp." strains CCM 168 and CCM 1405 and members of the genus Salinicoccus. Int J Syst Bacteriol 43, 245-248.

Wildes, H., Wittich, R. M., Timmis, K. N., Fortnagel, P. \& Francke, W. (1996). Degradation of chlorinated dibenzofurans and dibenzo- $p$ dioxins by Sphingomonas sp. strain RW1. Appl Environ Microbiol 62, 367-371.

Wu, C., Lu, X., Qin, M., Wang, Y. \& Ruan, J. (1989). Analysis of menaquinone compound in microbial cells by HPLC. Microbiology (English translation of Mikrobiologiia) 16, 176-178.

Yabuuchi, E., Yano, I., Oyaizu, H., Hashimoto, Y., Ezaki, T. \& Yamamoto, H. (1990). Proposals of Sphingomonas paucimobilis gen. nov. and comb. nov., Sphingomonas parapaucimobilis sp. nov., Sphingomonas yanoikuyae sp. nov., Sphingomonas adhaesiva sp. nov., Sphingomonas capsulata comb. nov., and two genospecies of the genus Sphingomonas. Microbiol Immunol 34, 99-119.

Yabuuchi, E., Kosako, Y., Fujiwara, N., Naka, T., Matsunaga, I., Ogura, H. \& Kobayashi, K. (2002). Emendation of the genus Sphingomonas Yabuuchi et al. 1990 and junior objective synonymy of the species of three genera, Sphingobium, Novosphingobium and Sphingopyxis, in conjunction with Blastomonas ursincola. Int J Syst Evol Microbiol 52, 1485-1496.

Zhang, D., Yang, H., Zhang, W., Huang, Z. \& Liu, S.-J. (2003) Rhodocista pekingensis sp. nov., a cyst-forming phototrophic bacterium from a municipal wastewater treatment plant. Int J Syst Evol Microbiol 53, 1111-1114 